\title{
Annual General Meeting
}

The 74th Annual General Meeting will be held in the Meeting Rooms of the Zoological Society of London, Regent's Park, London NW1, on Wednesday, July 51978 at $6 \mathrm{pm}$. The speaker will be Charles de Haes, Director General of the World Wildlife Fund International. The Business of Extinction, a 50-minute film on international trade in wildlife, will be shown. A wine and cheese supper will be served.

\section{Agenda}

1. Minutes of the 1977 Annual General Meeting

2. Presentation and discussion of Annual Report

3. Presentation and discussion of the Accounts and Auditors' Report

4. Election of Officers

5. Election of Vice-President

6. Election of Council Members

7. Vote of thanks to Zoological Society of London.

Council recommends that the following members should be re-elected as Officers of the Society for 1978-79:

President Professor Lord Zuckerman OM KCB DSc FRS

Chairman of Council Sir Peter Scott CBE DSc

Vice-Chairman of Council Lord Craigton PC CBE

Honorary Treasurer Ian D. Malcolmson TD

Honorary Secretary Richard Fitter

Honorary Editor Maisie Fitter

The following member is proposed for election as Vice-President:

Dr Harold J. Coolidge (USA)

Three members of Council retire at the Annual General Meeting and are not eligible for re-appointment for one year:

Jeffery Boswall

Dr Michael Brambell

Philip Wayre

Council has appointed the following to fill the vacancies and their names are submitted for confirmation:

J. M. Knowles

Dr R. D. Martin

The Hon. A. Tryon 


\section{Annual Report for 1977}

\section{Vice-Presidents and Council}

It is with great regret that we record the death of Sir Landsborough Thomson CB DSc on June 11 1977. He had been a member of Council since 1958 and a Vice-President since 1963.

Four new members were elected to Council: Lt Col J. P. Grant of Rothiemurchus MBE, who returns for a second term, Lord Dulverton CBE TD, Trustee of the British National Appeal of WWF and well known for his conservation-orientated approach to forestry, and Professor Peter Jewell of Cambridge University, a mammalogist who, together with the fourth new member of Council, David Jones (Senior Veterinarian, London Zoo), has a particular interest in the conservation problems of the Sahel.

\section{Membership}

At the beginning of the year the membership totalled 3482. The larger number of deletions and resignations than usual was probably the result of the subscription increase the previous year. At the end of 1977 membership stood at 3199.

\section{Oryx}

Three 96-page issues of Oryx were published, in February, July and December.

\section{International Meetings}

During 1977 FPS was represented by one or other of the Honorary Secretary, Honorary Editor and Assistant Secretary at the following meetings: IUCN Survival Service Commission, Morges, Switzerland, May; and Slimbridge, England, July; IUCN General Assembly, Geneva, April; Convention on International Trade in Endangered Species, Geneva, October; International Whaling Commission, Canberra, Australia, June, and Tokyo, Japan, December.

\section{Oryx $100 \%$ Fund}

Gifts to the Oryx $100 \%$ Fund in 1977 totalled $£ 4827$, of which $£ 630$ was earmarked for specific projects. In additional $£ 465$ was raised for Operation Zebra jointly with the World Wildlife Fund through the Sunday Times. This money is earmarked for projects relating to Grevy's zebra. Donations to the Fund were received from the Elvetham Charitable Trust, $£ 1000$; St Katharine's Fund, $£ 600$; Mrs M. L. Longman, $£ 550$; Miss M. E. Gibbs, $£ 500$; F. Hammer, $£ 500$; F. W. Bernard, $£ 100$; Miss W. Felce, $£ 100$; Mrs M. J. Hayne, $£ 100$; Mrs P. Sheridan, $£ 100$; Anonymous, $£ 100$; J. B. Constable, $£ 50 ;$ E. D. Medcalf, $£ 50 ;$ Mrs M. E. L. Nobles, $£ 50 ; K$. Richards, £50; S. Rostron, $£ 44$; $\mathrm{Mr}$ and Mrs C. J. Cadbury, $£ 30 ;$ C. A. Winnington Ingram, $£ 30 ;$ Miss M. R. Silverman, $£ 20$; Mrs J. M. Watt, £20; and Anonymous, $£ 20$. The Fund aided projects in Argentina, Brazil, Central America, Chad, Ghana, Seychelles, Sri Lanka, Tanzania, Thailand, and Zambia.

\section{Legacies and Gifts}

Four legacies were received: L. Sherriff, $£ 6500$; Lady Anstruther-Gough- 
Calthorpe, $£ 1000$; Mrs G. H. Soward, $£ 340$; Mrs R. E. S. Bell, $£ 100$. Gifts of $£ 20$ and over included anonymous donations of $£ 2000$ and $£ 20 ; F$. Hammer, $£ 200$; W. J. Foster, $£ 100$; F. W. Bernard, $£ 50$; Dr A. A. Spriggs, $£ 50$; New Moorgate Trust, $£ 1000$; Ernest Kleinwort Charitable Trust, $£ 100$, and Ofenheim Charitable Trust, $£ 200$.

\section{Otter Project}

In 1977 an Otter Haven Project was launched, financed by the Vincent Wildlife Trust, and administered by FPS. The project workers, Angela King and Angela Potter, aim to survey river systems in England and discover suitable areas for establishing otter havens. A report appeared in Oryx 14, 2.

\section{Trade Records Analysis of Flora and Fauna in Commerce}

FPS continues to administer the IUCN TRAFFIC Group which, early in 1977, moved into a separate office at 1 Marshall St W1. A continuing programme has been developed and adequate funding assured by IUCN. In October, Hazel Robinson joined the staff of TRAFFIC. Tim Inskipp continued his research projects, with grants from FPS, IUCN, WWF, RSPCA and RSPB, including a four-month visit to India to investigate trapping for the cage bird trade. The Chairman, John A. Burton, attended the special working session of the parties to the Washington Convention at Geneva in October, and meetings of the SSC in May and July.

\section{Office Work}

In 1977 the flow of correspondence to and from all parts of the world continued to increase. FPS now has over 100 Overseas Consultants in 70 different countries who keep us informed of news and developments in their part of the world. This information is of particular interest to the compiler of the Red Data Book, the Editor of Oryx and TRAFFIC. The Society continues to receive a vast selection of journals, all of which are thoroughly scanned. By the end of 1977 the staff were as follows (*part-time): John A. Burton*, Assistant Secretary; David Helton*, Assistant Editor; Mrs Kay Gordon, Office Manager; Miss Vivien Gledhill; Miss Christine Jones; and Mrs Stephanie Waine* (from September). It was with great regret that at the end of the year we said goodbye to Christine Jones, who has joined the Wellcome Institute as an animal technician.

\section{Film Library}

In 1977 we received 110 bookings for films, showing to a total audience of over 10,000. This slight reduction from 1976 was in part due to the removal of three films because of general deterioration: Forest from the Dawn of Time, The Silent Watcher and The Swallowtail Butterfly. One new film was added to the Library, The Woodman and the Wild, made by Lord Dulverton, an FPS Council Member.

\section{Christmas Cards}

Because of large stocks in hand the Society did not produce a new Christmas card. Sales totalled 20,000 and net profit was $£ 671.39$. 


\section{Members' Meetings}

The Annual General Meeting was held on July 5. Professor V. C. WynneEdwards, FRS Chairman of the Scientific Authority for Animals, and Professor A. G. Bannikov, Vice President of the Society, were the guest speakers. After a buffet supper The Passing of the Leviathan was shown, by courtesy of Anglia Television.

In 1977 three Members' Meetings were held. On February 23 Dr R. E. Stebbings addressed an audience of more than 200 on an expedition to Ecuador to study bats, and Andrew Laurie gave an illustrated talk on Asian rhinos; after a buffet supper The Last Stronghold, a film in the FPS Film Library, was shown. On October 26 Dr Robert Olivier, Co-Chairman of the Survival Service Commission's Asian Elephant Group, gave an illustrated talk on Asian elephants, and the 'World About Us' film, The Elephant Run, was shown. On November 23 a joint symposium was held with the Conservation Committee of the British Herpetological Society on the natterjack toad, sand lizard, smooth snake and other British amphibians and reptiles.

\section{Auditors' Report}

\section{To: The Council and Members of the Fauna Preservation Society}

Accounts for the year ended 31st December 1977

We have completed the audit of the books and accounts of the Society for the year ended 31st December 1977 and report thereon as follows:

\section{Life Membership Fund}

The balance standing to the credit of the Fund is now $£ 13,739$. This is after crediting $£ 1,177$ in respect of Life Membership Subscriptions received during the year and transferring $£ 115$ to the General Reserve Account which represents the value of subscriptions of those life members whose membership ceased during the year.

\section{Film Purchases - Reserve Fund}

To the opening balance of $£ 1,391.96$ has been added $£ 520.21$ transferred from Income and Expenditure Account. Purchases during the year amounted to $£ 276.02$, leaving a balance to be carried forward of $£ 1,636.15$.

\section{General Reserve Account}

The balance at 1st January 1977 was

to which has been added:

Legacies

Fees of deceased life members

Profit on sale of Investments

$£ 68,814.42$

$7,847.59$

115.00

$1,159.71$

$77,936.72$

from which has been deducted the excess of Expenditure over income for the year

$4,435.95$

giving a balance at the year end of

$£ 73,500.77$ 
Red Data Book Account

Receipts received during the year exceeded expenditure by $£ 976.26$ from which has been deducted the opening debit balance of $£ 946.17$ leaving a credit balance to be carried forward of $£ 30.09$.

\section{Investments and Deposits}

The total investments and deposits of the Society at 31st December 1977 at cost amounted to $£ 88,773.07$, including $£ 4,000$ of the Oryx $100 \%$ Fund, and the market value at that date was $£ 99,452$, showing a net appreciation of $£ 10,679$.

\section{Surplus}

The surplus of assets over liabilities at the end of the year amounted to $£ 88,906.01$ compared with $£ 81,937.21$ at the end of the previous year.

Oryx $100 \%$ Fund

The balance at 1st January, 1977 was

to which has been added:

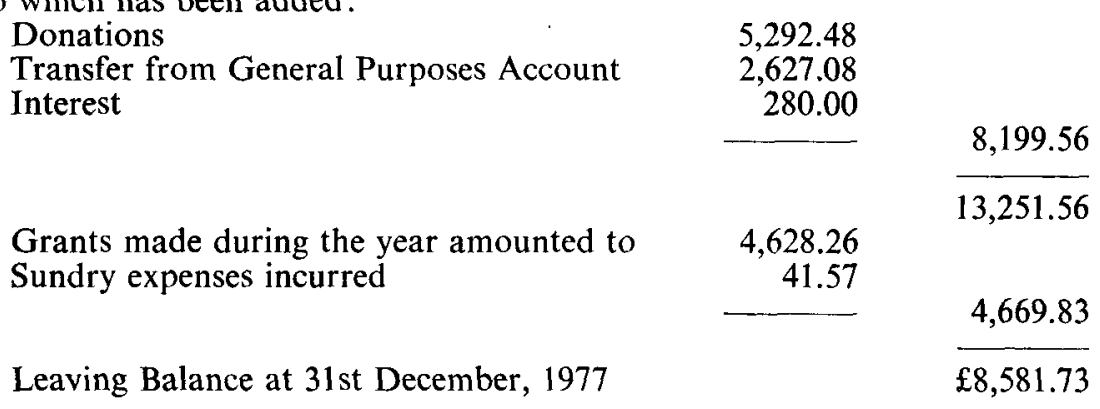

This balance is represented by $£ 4,000$ Local Authority Bonds and $£ 4,581.73$ cash at bank.

\section{TRAFFIC Account}

To the opening balance of $£ 894$ has been added Grants of $£ 6,462.89$. Expenditure amounted to $£ 6,828.28$ leaving a balance of $£ 528.61$ to be carried forward.

\section{Otter Account}

Grants received during the period of operation were $£ 4,150.00$, and expenditure incurred at $£ 3,920.66$ resulted in a balance of $£ 229.34$ to be carried forward. 


\section{ORYX 100\% FUND Year ending 31st December, 1977}

\begin{abstract}
Balance at 1st January Income for year-

Donations

Transfer from General Fund

Interest
\end{abstract}

\section{INCOME}

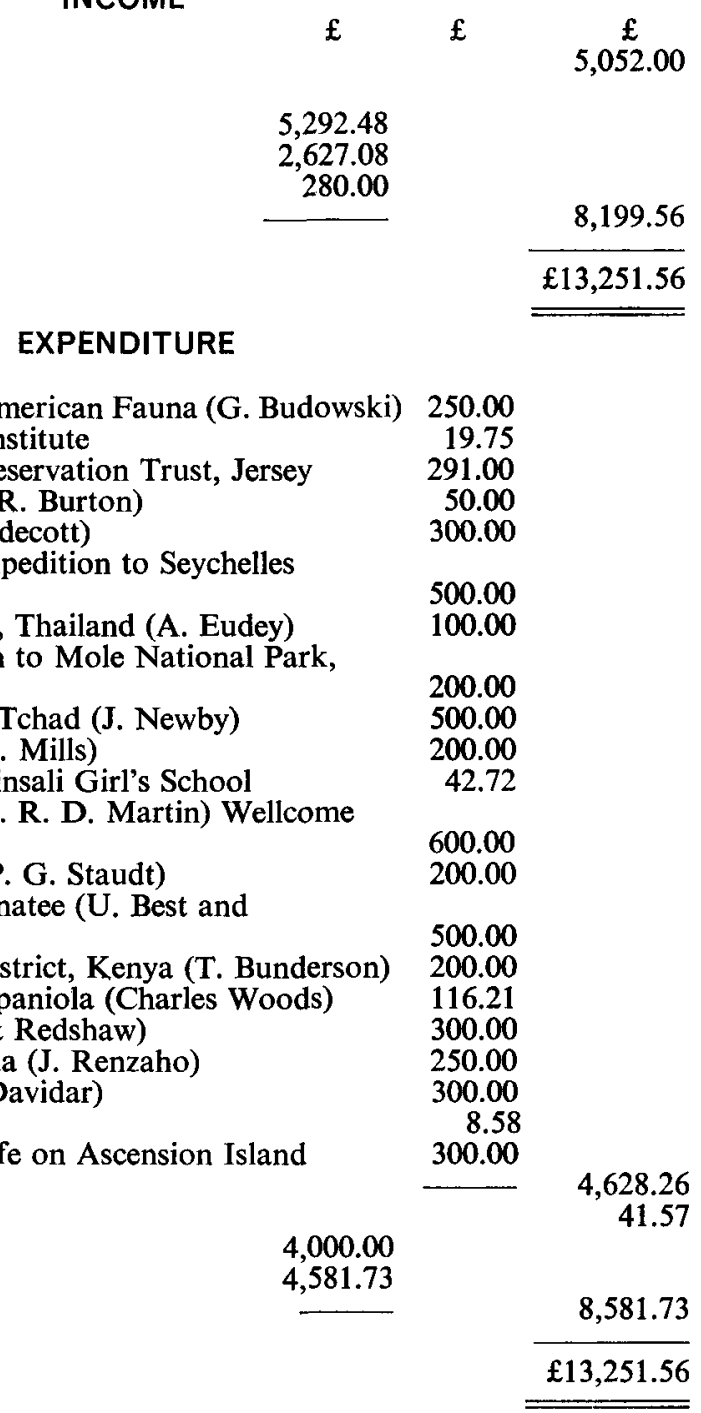

\section{GRANTS}

Status of Endangered Central American Fauna (G. Budowski)

Books for Serengeti Research Institute

Pygmy Hog Study-Wildlife Preservation Trust, Jersey

Expedition to Liverpool Land (R. Burton)

Distribution of Siamang (J. Caldecott)

Second Aberdeen University Expedition to Seychelles (P. Racey)

Research in Huay Kha Khaeng, Thailand (A. Eudey)

Aberdeen University Expedition to Mole National Park, Ghana (M. Gorman)

Petrol for Anti-Poaching Unit, Tchad (J. Newby)

Alfaques Preservation, Spain (S. Mills)

Books for Library, Zambia-Chinsali Girl's School

Sexing Monomorphic birds (Dr. R. D. Martin) Wellcome Institute

Pampas Deer in Argentina (J. P. G. Staudt)

Distribution of Amazonian Manatee (U. Best and

B. S. Donning)

Animals in Lamu \& Garissa District, Kenya (T. Bunderson)

Solenodon/Plagiodontia on Hispaniola (Charles Woods)

Tana Mangabey (Homewood \& Redshaw)

Akagera National Park, Rwanda (J. Renzaho)

Nilgiri Tahr in Nilgiris (E. C. Davidar)

Mole National Park (Library)

Credit-Conservation of Wildlife on Ascension Island

Sundry items and bank charges

Local Authority loans

Balance at bank 


\section{Balance sheet}

1976

LIABILITIES

\begin{tabular}{c}
$\stackrel{£}{3,383}$ \\
1,590 \\
\hline 4,973
\end{tabular}

Balance, being excess of assets over liabilities:-

Life Membership Fund

Balance at 1st January, 1977

Add: Fees received during year

Sundry Creditors and Provisions

Receipts in Advance

Subscriptions

732.00

$6,011.03$

Add: Fees received during year

$12,677.00$

$1,177.00$

$13,854.00$

12,677

Deduct: Transfer to General Reserve Account :Fees of deceasedLife Members

$115.00 \quad 13,739.00$

Film Purchases-Reserve Fund

Balance at 1st January, 1977

Add: Transfer from Income and Expenditure Account

$1,912.17$

Deduct: Purchases during year

276.02

General Reserve Fund

Balance at 1st January, 1977

Add: Legacies received during year

Transfer from Life Membership Fund

Profit on Sale of Investments

Deduct: Excess of Expenditure over Income for the year

68,814

Deduct: Expenditure during year

Red Data Book Account

Balance at 1st January, 1977

Add: Cash received during year

$£ 86,910$

$68,814.42$

$7,847.59$

115.00

$1,159.71$

$77,936.72$

$4,435.95$

$73,500.77$

(946.17)

$5,671.21$

$4,725.04$

$4,694.95$

$1,636.15$

30.09

$£ 94,917.04$

We have examined the above Balance Sheet and accompanying Income and Expenditure Account, the Receipts and Payments Accounts relating to the Oryx $100 \%$ Fund, the TRAFFIC and Otter Accounts, with the books and accounts of the Society and with the information and explanations supplied and certify them to be in accordance therewith. We have verified the bank balance and the investments of the various funds.

Knightway House,

20 Soho Square,

London W1V 6QJ

NORTON KEEN \& CO.

23rd March 1978

Chartered Accountants 


\section{1st December 1977}

1976

\section{ASSETS}

$£$

Office Furniture and Equipment-cost at 1st January

Expenditure in year

680.00

33.48

713.48

Less: Amount written off in year

203.48

680

Stocks in Hand

1,970

77,437

(at or under cost)

Investments (at cost) See page 282

$1,835.05$

$77,773.07$

Sundry Debtors and Payments in Advance

1,168 Income tax recoverable on investments

1,550 Income tax recoverable on Deeds of Covenant

Balance at Bank and cash in Hand

Deposit Account

General Account 


\section{Income and Expenditure Account}

\section{GENERAL PURPOSES ACCOUNT}

1976

$£$

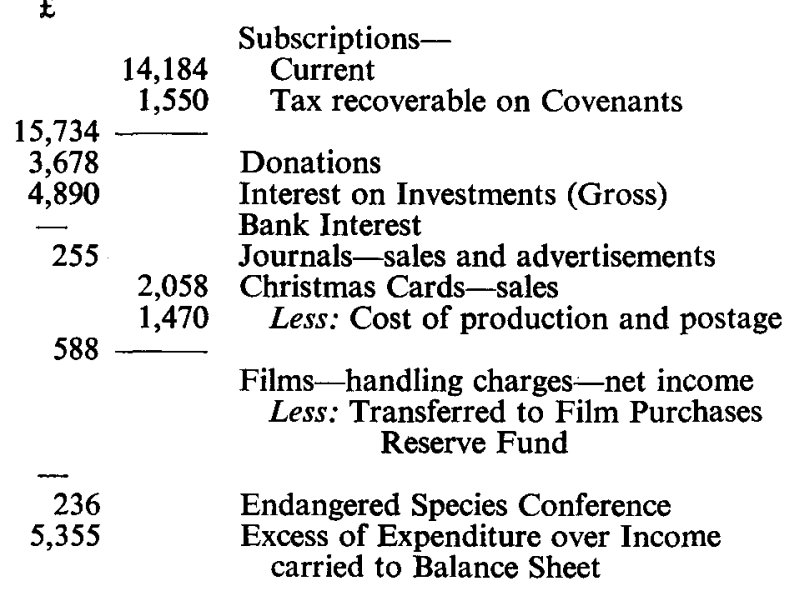

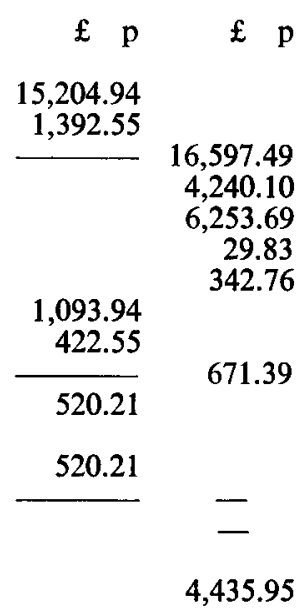

$15,204.94$

$1,392.55$

$16,597.49$

$4,240.10$

,253.69

29.83

, 093.94

$\quad 671.39$

520.21
$4,435.95$ 


\section{for the year ended 31st DECEMBER 1977}

1976

\section{EXPENDITURE}

f

7,190 Salaries-Office Manager and secretarial staff

$£ \quad p$

$\underset{7,533.41}{£}$

$4,199.66$

3,532 Consultancy fees

150 Editor's honorarium

627 Editor's expenses including Survival Service Commission of IUCN

188.16

Hon. Secretary's overseas expenses including S.S.C. of IUCN

Less: Contribution from World Wildlife Fund

227 Hon. Secretary's local travelling

736 Assistant Secretary's travelling expenses Less: Contribution from IUCN

6,813 Production of Journal

1,045 Postage for Journal

Office-Service charge

Regent's Park-net

Less: Donation from Zoological Society

1,249 Office and miscellaneous expenses

1,126 Stationery

1,135 Telephone

134 Advertising

1,235 Postage

123 Films-insurance

533 Accountancy and audit

35 Income tax-accountancy charges

555 Grants and subscriptions to other bodies

242 Transfer to ORYX $100 \%$ Fund

1,000 Transfer to Traffic Account

1,000 Transfer to Red Data Book

268 Furniture and equipment-amount written off

431 Sundry sales-deficit

$1,654.09$

450.00

— $1,204.09$

501.76

592.09

430.00

$7,911.98$

$1,444.15$

162.09

$9,356.13$

890.00

250.00

640.00

978.02

766.99

$1,331.81$

233.65

$1,161.61$

75.40

720.00

40.00

400.00

$2,627.08$

-

203.48

24.47

223.40

$£ 32,571.21$ Game Fair Exhibit

\section{Otter Account Period to 31st December, 1977}

Receipts

£ $\mathrm{p}$

$\mathfrak{f} \mathbf{p}$

Expenditure:

Salaries

$4,150.00$

Office Expenses

Balançe at 31st December 
Investments (at cost)

4,136.00 Greater London $91 \%$ Stock 1980

$4,120.22$

2,500.00 Gestetner Holdings $10 \%$ Culs. 1990/95

3,300.00 Imperial Group Ltd. 8\% Culs. 1985/90

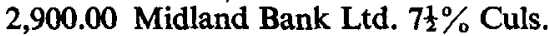
1983/93

2,000.00 Slough Estates Ltd. 10\% Culs. 1987/90

850.00 Babcock \& Wilcox Ltd. Ordinary Shares $25 p$

650.00 E.M.I. Ltd. Ordinary Shares 50p

100.00 Sedgwick Forbes Holdings Ltd. Ordinary $10 \mathrm{p}$ Shares

262.50 Viking Resources Trust Ordinary 25p Shares

91.50 Selection Trust Ltd. Ordinary 25p Shares

$3,157.30$

$2,452.17$

$2,420.44$

$3,012.80$

$2,450.81$

$1,959.77$

$1,989.20$

$1,299.68$

$2,134.46$

$20,690.0081 \%$ Treasury Stock $1987 / 90$

$17,853.06$

1,687.00 Imperial Chemical Industries Ltd. Ordinary Stock

$6,121.31$

3,000.00 Steetly Co. Ltd. 7\% Culs. 1984/88

$2,747.85$

1,833.75 Trustees Corporation Ltd. 25p Ordinary Shares

$7,575.65$

44.00 St. Pancras Housing Society Ltd. $2 \frac{1}{2} \%$ Conversion Stock

222.00 Shell Transport and Trading Co. Ltd. 25p Ordinary Shares

3,303.35

1,375.00 Scottish Eastern Investment Trust Ltd. 25p Ordinary Shares

210.50 Royal Insurance Co. Ltd 25p Ordinary Stock Units

$5,995.00$ $2,627.00$

1,110.00 North American Investment Co. Ltd.

3,000.00 Deposits with Local Authorities 3,000.00

77,773.07

\section{'TRAFFIC Account' Year to 31st December 1977}

Balance at 1st January<smiles>[13CH3]</smiles>

Grants received during year

Expenditure:

Consultants

Salaries

Travelling

Rent

Office expenses

894.00

$6,462.89$

$7,356.89$

$3,000.00$

996.34

$1,000.00$

$1,052.18$

779.76

Balance at 31st December

I528. 


\section{Application for Membership}

\section{The Fauna Preservation Society}

c/o The Zoological Society of London, Regent's Park, London NW1 4RY

Please enrol me as a member of the Society

Name (BLOCK LETTERS) Please state Mr/Mrs/Miss or title

\section{Address}

The minimum subscription for Ordinary Members is $£ 5$, US $\$ 12.50$, for Benefactors $£ 10$, US $\$ 25$, payable on January 1 st. A Banker's Order saves time, expense and reminders. The value of any subscription is greatly increased if it is paid under a seven-year Deed of Covenant (UK standard-rate income taxpayers only) and this entails no extra cost whatever: write for Covenant forms to the Secretary.

Life membership fees:

Age: Under 41 , £200, US $\$ 485$; age $41-60, £ 150$, US $\$ 385$; age 61 and over, $£ 75$, US $\$ 185$.

\section{Banker's Order}

Bank

Address of Bank

Please pay for the Credit of The Fauna Preservation Society, Barclays Bank Ltd. Camden Town, London NW1, my subscription of $\{. . . . . . . . . .$. due on 1 st January 19 , and a similar amount on 1 st January each year until further notice.

Signature Date 


\title{
East African Wildlife Journal
}

\author{
Edited by J. B. Sale
}

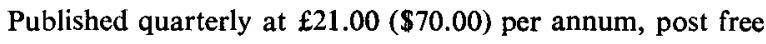

A Selection of Papers from Volume 14, No. 3, June 1978

Barbara M. Leuthold and Walter Leuthold: Ecology of the giraffe in Tsavo East National Park, Kenya

David B. Hull: Aberrations in the coat colour patterns of black and white Colobus monkeys

R.J. Douthwaite: Geese and Red-knobbed Coot on the Kafue Flats in Zambia, 1970-1974

Jonathan Baranga: Splenic weights and their possible relationship to adrenocortical function in a wild population of Rousettus aegyptiacus $\mathrm{E}$. Geoffroy

\section{Notes and Records}

C.L. Mollel: Cervico-vaginal prolapse in an African elephant

Robert A. Cheke: Records of birds and their parasites from the Cherangani Mountains, Kenya R.T. Wilson: Notes on the crocodile Crocodylus niloticus, in Darfur, Western Sudan

T.U. Obi: Traumatic granuloma in an African elephant (Loxodonta africana) and its treatment with Yatren ${ }^{\circledR}$-Casein

Book Reviews

Notice

Subscriptions to this journal should be accompanied by the appropriate remittance and sent to Blackwell Scientific Publications Ltd., Osney Mead, Oxford OX2 0EL, England

\section{International Zoo Yearbook 18}

\section{Edited by \\ P. J. S. Olney}

Special subject Penguins

The international meeting ground of biologists, conservationists and zoo-keepers. This year's forum subject - penguins, their management and breeding in captivity and related research (17 papers). Plus 51 papers on all aspects of zoo animal care and conservation. Plus 200 page reference section - directory of world zoos and aquaria; new zoo buildings; breeding records; rare animal census and studbooks. 450 pages, over 100 photographs and drawings.

Hardcover $£ 14$; softcover $£ 12$

From: Publications Dept (IZY), The Zoological Society of London, Regent's Park, London NW1 4RY.

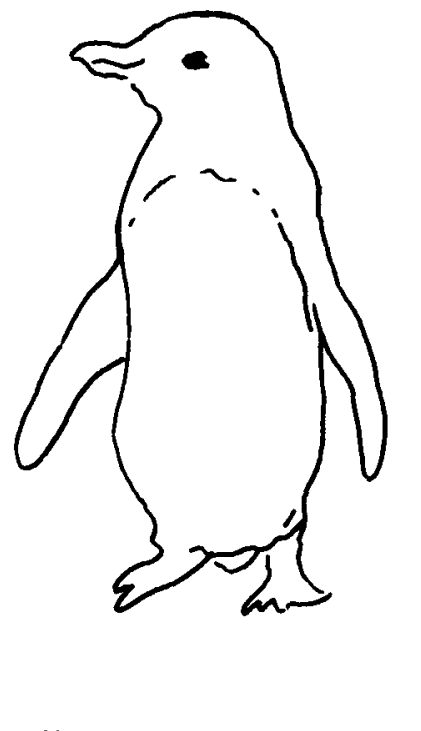




\section{Jourenal of 300000000}

Editor: R.J. Roberts

Unit of Aquatic Pathobiology, University of Stirling, Scotland

Associate Editor: R. Wootten

Marine Laboratory, Victoria Road, Aberdeen, Scotland

\section{Editorial Board}

$\begin{array}{ll}\text { O.N. Bauer U.S.S.R. } & \text { P. de Kinkelin France } \\ \text { G.R. Bell Canada } & \text { O. Ljungberg Sweden } \\ \text { N.N. Fijan Yugoslavia } & \text { A.L.S. Munro Scotland } \\ \text { P. Ghittino Italy } & \text { T. Sano Japan } \\ \text { J.C. Harshbarger U.S.A. } & \text { S.F. Snieszko U.S.A. } \\ \text { P.M. Hine New Zealand } & \text { J.P.Stevenson England } \\ \text { G.L. Hoffman U.S.A. } & \text { K.E. Wolf U.S.A. }\end{array}$

The Journal of Fish Diseases is designed for the publication of scientific ,papers of the highest standard on all aspects of disease in wild and cultured fishes and shellfishes. Its interests include: host-pathogen relationships; studies of fish pathogens; patho-physiology; diagnostic methods; nutritional problems; therapy; epidemiology; descriptions of new diseases. Reports on work in these fields have hitherto been scattered throughout the literature, but the growing interest in fisheries research has stimulated a need for a medium in which its various aspects can be published in a single journal. Although it is devoted principally to the publication of the results of significant research, the journal will also publish occasional review articles, shorter communications and book reviews. The wide geographical distribution and range of expertise of the eminent editorial board reflect the international character of the journal, and the enthusiasm of both potential subscribers and contributors encourages the belief that the Journal of Fish Diseases will make a substantial contribution to productive communication between scientists throughout the world.

The Journal of Fish Diseases is published quarterly at $\mathbf{E} 18.00$ (U.K.), £22.00 (overseas), $\$ 50.00$ (U.S.A. and Canada) per annum post free. Subscriptions and requests for specimen copies should be sent to the publishers at the address below 


\section{FPS Wildlife Film Library}

Unless otherwise stated all films are $16 \mathrm{~mm}$ in colour with soundtrack. The charge quoted includes VAT. To book a film please write to the Films Officer, FPS, c/o Zoological Society, Regent's Park, London NW1 4RY. Tel: 01-586 0872.

Charges: We have been forced to increase hiring charges on new films, but charges on older ones have been reduced to $£ 2$ each, or $£ 1$ each if hired with a film from the main list. (The prices are for a single showing. Each additional one is $£ 2$, or $£ 1$ for older films.)

LATEST ADDITION: At the Crossroads: American wildlife's struggle for survival. Shows endangered species never filmed before. Winner of six awards. Stouffer. 26 mins. $£ 7.50$.

The Last Stronghold: Flying snakes, flying squirrels, and other wildlife in the Malaysian rain forests. WWF Malaysia. 30 mins. $f 5$.

In Search of the Bowhead Whale: Aerial and underwater photography of bowhead and beluga whales off Alaska. 49 mins. $£ 5$.

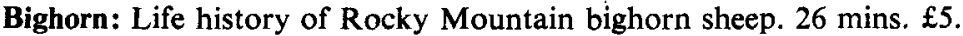

Ivory Poachers: East African Wildlife Society documentary of the fight against Tsavo elephant poachers. 30 mins. $f 5$.

On the Third Day: Rare and beautiful plants, insects and vertebrates of the Cape of Good Hope. South African Wildlife Society. 26 mins. $£ 5$.

To Catch a Rhino: Translocation of white rhinos from the Umfolozi Reserve. South African Tourist Corporation, 1962. 20 mins. $£ 3$.

Everglades Region: How wildlife adjusts to seasonal fires and floods. 24 mins. $£ 3$.

Lake Wilderness: Wildlife of St Lucia Lakes. SATOUR. 20 mins. $£ 3$.

Blesbok: Life history of this South African antelope. 15 mins. $£ 2$.

Whales, Dolphins and Men: Lives, songs and commercial exploitation of cetaceans. BBC Horizon film. 50 mins. $£ 5$.

Uganda Kob: Territorial and ritualized mating behaviour of this antelope. 20 mins. $£ 2$.

Last of the Wild: Rare and endangered species of the world, their habitats and predators. 3 reels. 110 mins. $£ 5$.

\section{Older Films}

$£ 2$ each, or $£ 1$ if hired with a film from the main list

Peace Game: South Africa's wildlife. sATour. 25 mins.

Saiga Saga: Conservation of the saiga antelope. Russian commentary with English subtitles. Soviet Peace Committee. 16 mins.

Koala: Complete life history. H.J. Pollock. 24 mins.

African Lion: Taken by A.I.M. Hepburn in the Kruger National Park. Magnetic sound track. 12 mins.

Mallee Fowl: Nesting habits of a 'mound-builder'. CSIRO Film Unit. 11 mins.

Marloo, the Red Kangaroo: By H.J. Pollock. 25 mins.

Le Aye Aye de Madagascar: Black and white. French commentary. By J.-J. Petter and the Service du Film de Recherche Scientifique. 22 mins.

Penguins of Macquarie Island: King, gentoo, rockhopper and royal penguins. 13 mins. 


\section{ORNITHOLIDAYS}

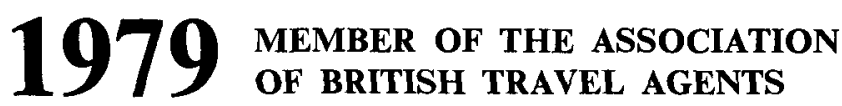

HOLIDAYS ORGANISED BY

BIRDWATCHERS FOR BIRDWATCHERS

Ceylon

India

Florida

California

The Seychelles

Kenya

Israel

Morocco

Tunisia

Turkey

Arctic Norway

S. W. Spain
Majorca

Greece

The Camargue

Yugoslavia

Lake Neusiedl

Austrian Alps

Hungary

Romania

Central Wales

Isles of Scilly

Isle of Mull

Isle of Islay

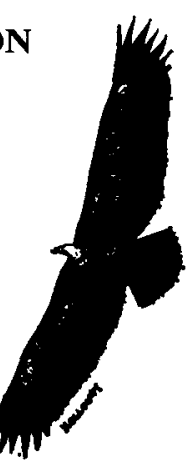

The Solway

The Cairngorms

Hebridean Cruise

Dorset

New Forest

West Sussex

Suffolk

The Farnes \& Bass

\section{LAWRENCE G. HOLLOWAY ORNITHOLIDAYS (Regd.)}

(WESSEX TRAVEL CENTRE)
1/3 VICTORIA DRIVE, BOGNOR REGIS, SUSSEX, ENGLAND PO21 2PW

Telephone 0243321230 